\title{
Deleterious Effects of IL-9-Activated Mast Cells and Neuroprotection by Antihistamine Drugs in the Developing Mouse Brain
}

\author{
JULIANA PATKAI, BETTINA MESPLES, MARIE-ALIETTE DOMMERGUES, GAËLLE FROMONT, \\ ELISABETH M. THORNTON, JEAN-CHRISTOPHE RENAULD, PHILIPPE EVRARD, AND \\ PIERRE GRESSENS \\ INSERM E-9935 and Service de Neurologie Pédiatrique, Hôpital Robert-Debré, 75019 Paris, France \\ [J.P., B.M., M.A.D., P.E., P.G.], Service d'Anatomopathologie, Institut Mutualiste Montsouris, 75014 \\ Paris, France [G.F.], Department of Veterinary Studies, University of Edinburgh, Edinburgh, EH8 9YL, \\ U.K. [E.M.T.], and Ludwig Institute for Cancer Research and Experimental Medicine Unit, Université \\ Catholique de Louvain, 1200 Brussels, Belgium [J.C.R.]
}

\begin{abstract}
Elevated mean IL-9 serum levels have been observed in human neonates who will later develop cerebral palsy. In earlier studies, using a newborn mouse model of excitotoxic lesions mimicking those described in human cerebral palsy, we found that IL-9 pretreatment exacerbated brain damage produced by intracerebral injections of the glutamatergic analog ibotenate. Among its different cell targets, the Th2 cytokine IL-9 is a mast cell growth and differentiation factor that can cause mast cells to release various substances including histamine. In the present study, we sought to determine whether the deleterious effects of IL-9 in our mouse model were mediated by mast cells through histamine release. All mouse pups were pretreated with intraperitoneal injections of IL-9 or saline between postnatal days (P) $\mathrm{P} 1$ and P5. Immunohistochemistry for murine mast cell protease-1 performed on P5 showed an increased density of labeled cells in the neopallium of IL-9-treated Swiss pups as compared with controls. Western blot analysis confirmed the increased murine mast cell protease-1 brain content of IL-9-treated Swiss
\end{abstract}

ABSTRACT

mice. IL-9 pretreatment had no significant effect on ibotenateinduced excitotoxic brain lesions in mast cell-deficient P5 pups (WBB6F1/J kit ${ }^{\mathrm{W} / \mathrm{W}-\mathrm{v}}$ ), whereas IL-9 exacerbated these lesions in the control littermates with normal mast cell populations. Finally, cromoglycate or antihistamine drugs significantly reduced ibotenate-induced brain lesions in IL-9-treated Swiss pups. Taken together, these data suggest that recruitment of cerebral mast cells with histamine release may contribute to the exacerbation of neonatal excitotoxic brain lesions produced by IL-9. Neuroprotective strategies targeting mast cells may be useful in some neonates at risk for cerebral palsy. (Pediatr Res 50: 222-230, 2001)
Abbreviations
mMCP, murine mast cell protease
NMDA, $N$-methyl-D-aspartate
$\mathbf{P}$, postnatal day
TNF- $\alpha$, tumor necrosis factor- $\alpha$

Pathophysiologic concepts for cerebral palsy have changed over the last decade (1-7). Recent hypotheses have implicated multiple preconceptional and prenatal factors, such as hypoxiaperfusion failure, genetic factors, growth factor deficiency, and excess production of cytokines. In a striking retrospective study, mean levels of perinatal circulating cytokines - including IL- $1 \beta$, IL-6, IL-8, IL-9, and TNF- $\alpha$-were higher in patients with subsequent occurrence of cerebral palsy than in control subjects (8). In that study, although the numbers of included patients were

Received September 6, 2000; accepted December 12, 2000.

Correspondence and reprint requests: Pierre Gressens, M.D., INSERM E 9935, Hôpital Robert-Debré, 48 Blvd Sérurier, F-75019 Paris, France; e-mail: gressens@idf.inserm.fr

Supported by the INSERM, the Fondation pour la Recherche Médicale, the Fondation Grace de Monaco, and the Société d'Etudes et de Soins pour les Enfants Paralysés et Polymalformés. J.C.R. is a research associate with the Fonds National de la Recherche Scientifique (Belgium). limited, levels of proinflammatory cytokines (IL-1- $\beta$, IL-6, IL-8, and $\mathrm{TNF}-\alpha$ ) were associated with one another, but no correlation was detected between IL-9 levels and the levels of the other cytokines tested. Although further studies will be necessary to confirm this initial observation, these data could suggest the existence of a subpopulation of cerebral palsy patients characterized by increased levels of circulating IL-9 at birth. A better understanding of the mechanisms bridging IL-9 blood level elevation and brain damage might open up new therapeutic possibilities for preventing cerebral palsy in infants with high circulating IL-9 levels.

Intracerebral injection of ibotenate, a glutamate analog, to newborn mice produces histologic lesions mimicking the brain lesions frequently associated with cerebral palsy, such as cystic periventricular leukomalacia and hypoxic-ischemic or ischemic- 
like cortical damage (9-10). The thickness of the murine periventricular white matter is much smaller than in humans, making some inferences between rodents and human potentially difficult. However, ibotenate-induced white matter lesions in newborn mice mimic several aspects of the human cystic periventricular leukomalacia, including their periventricular location, their initial cystic appearance, their secondary evolution toward a glial scar, and the discrete ontogenetic window of sensitivity of the periventricular white matter to ibotenate-induced damage (9). In this well-characterized mouse model, pretreatment with proinflammatory cytokines (IL-1 $\beta$, IL-6, or TNF- $\alpha$ ) or with IL-9 increased the extent of the excitotoxic brain lesions (11). These deleterious effects of proinflammatory cytokines were mediated in part by the recruitment of brain macrophages/microglial cells. However, IL-9 had no detectable effects on this cell population, suggesting a separate mechanism of action.

IL-9 is produced by activated Th2 lymphocytes and is active on various immune cells including mast cells, B lymphocytes, $\mathrm{T}$ thymocytes, eosinophils, erythroid progenitors, and myeloid progenitors (12). Mast cells are present in the brain, including the neopallium, where their numbers increase during early postnatal development (13-17). Mast cells are derived from the pluripotent hematopoietic stem cells in the bone marrow. Their differentiation is dependent on tissue production of stem-cell factor and the expression of the corresponding KIT receptor on mast cell precursor cell surface. Mast cells can produce a variety of potentially toxic factors including histamine, serotonin, neutral proteases, cytokines, chemokines, and free radicals (18). Mast cells have been implicated in the pathophysiology of brain lesions associated with multiple sclerosis, Guillain-Barré syndrome, and Gayet-Wernicke encephalopathy (19). Techniques for detecting mast cells include toluidine blue staining (heparin-containing granule labeling) and immunohistochemistry with antibodies to various types of mast cell proteases. Immature mast cells enter the tissues, where they differentiate, taking on phenotypic features (predominance of heparin-containing or serotoninergic granules, predominant expression of some proteases, etc.) dependent on tissue type (20). In aggregate, these data suggest that mast cells may mediate the deleterious effects of IL-9 on the neonatal brain.

The goal of the present study was to investigate whether mast cells mediate the ability of IL- 9 pretreatment to exacerbate ibotenate-induced lesions in our mouse model of neonatal excitotoxic brain damage. Accordingly, we studied the effects of IL-9 pretreatment on density and phenotype of brain mast cells. To further confirm the implication of mast cells, the effects of IL-9 on excitotoxic brain lesions were studied in mast cell-deficient mice. Finally, the potentially deleterious effects of mast cell degranulation and histamine release on excitotoxic lesions were analyzed by using inhibitors of mast cell degranulation and antihistamine drugs.

\section{METHODS}

All experimental protocols and procedures were approved by our institutional review board and complied with INSERM guidelines.
Excitotoxic brain lesions. Ibotenate (Sigma Chemical Co, St. Louis, MO, U.S.A.) is a glutamate analog with effects on NMDA and metabotropic receptors, but not on $\alpha$-3-aminohydroxy-5-methyl-4-isoxazole or kainate receptors. Ibotenate was diluted in PBS containing $0.02 \%$ acetic acid. The following protocol was used for ibotenate administration to mouse pups. All ibotenate injections were administered on P5. One hour after the last injection of cytokines or PBS, intracerebral injections of $10 \mu \mathrm{g}$ of ibotenate were performed as previously described (9-11, 21-23). Briefly, after ether anesthesia of the pups, the injections were given under a warming lamp using a 26-gauge needle on a 50- $\mu \mathrm{L}$ Hamilton syringe mounted on a calibrated microdispenser. The needle was inserted $2 \mathrm{~mm}$ under the external surface of the scalp skin in the frontoparietal area of the right hemisphere, $2 \mathrm{~mm}$ from the midline in the lateral-medial plane, and $3 \mathrm{~mm}$ from the junction between the sagittal and lambdoid sutures in the rostrocaudal plane. Two $1-\mu \mathrm{L}$ boluses were injected $30 \mathrm{~s}$ apart. In all cases, the tip of the needle reached the periventricular white matter (some animals injected with toluidine blue confirmed the correct positioning of the needle). After the injections, the pups were returned to their dams.

Five days after intracerebral ibotenate injection (e.g. on P10), the pups were decapitated, and their brains were fixed in formaldehyde for $5 \mathrm{~d}$. After embedding in paraffin, $15-\mu \mathrm{m}$ sections were cut in the coronal plane, from the frontal to the occipital pole. Every third section was stained with cresyl violet. This permits accurate and reproducible determination of the maximal sagittal frontooccipital diameter (which is dependent on the number of sections containing the lesion and the width of each section) of both the cortical plate and periventricular white matter lesions. Here, we defined the maximal diameter as the length of the lesion along the sagittal frontoparietal axis. We used this measure as an index of lesion size. Throughout the study, two investigators blinded to the treatment groups of the animals determined the size of the lesion in each pup. The numbers of pups in each experimental group (see below) are shown in Table 1.

Effects of IL-9 pretreatment on excitotoxic lesions. Mouse recombinant IL-9 (Endogen, Woburn, MA, U.S.A.), in a dose of $40 \mathrm{ng}$ diluted in $5 \mu \mathrm{L}$ of PBS, was injected intraperitoneally twice a day (between $0800 \mathrm{~h}$ and $1000 \mathrm{~h}$ and between $1800 \mathrm{~h}$ and $2000 \mathrm{~h}$ ) on P1 to P4 and once a day (between $0800 \mathrm{~h}$ and 1000 h) on P5 to Swiss mice (Janvier, Le Genest-St-Isle, France). Control Swiss pups received PBS alone. One hour after the last intraperitoneal injection, pups received an intracerebral injection of ibotenate as described above.

Effects of IL-9 pretreatment on brain mast cells: immunohistochemistry and Western blot analysis of $\mathbf{M M C P}-1$. In this set of experiments, Swiss pups pretreated with IL-9 or with PBS as described above were decapitated on P5. None of these pups received an excitotoxic challenge. The brains were rapidly frozen at $-80^{\circ} \mathrm{C}$ and stored at this temperature until further examination.

For immunohistochemical analysis, we cut $20-\mu \mathrm{m}$ cryostat sections in the coronal plane through the frontoparietal neopallium, which was the ibotenate injection site in the experimental groups described above. After methanol-acetone fixa- 
Table 1. Experimental groups exposed to intracerebral ibotenate administration

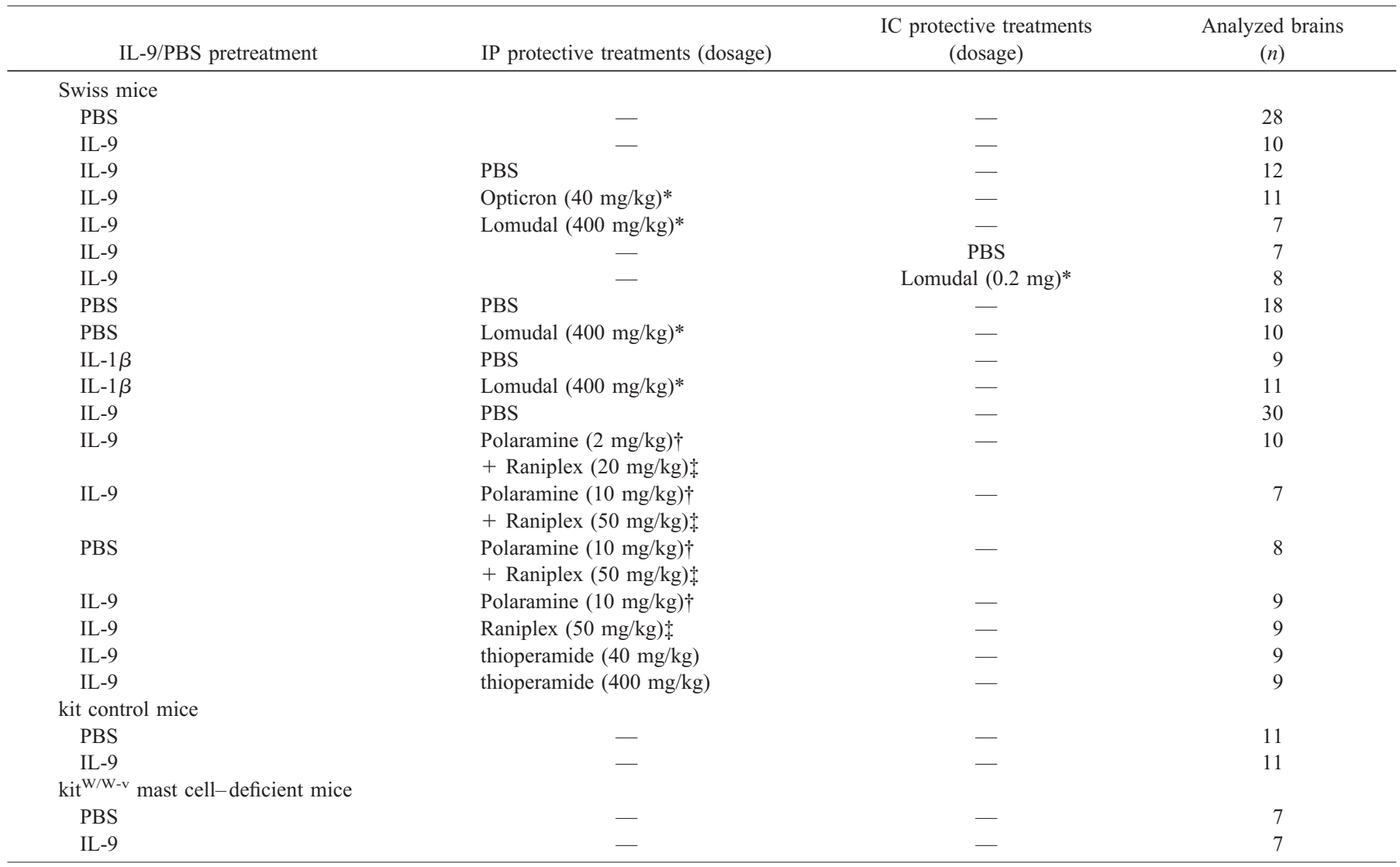

* cromoglycate; $\uparrow$ dexchlorpheniramine; $\$$ ranitidine.

IP, intraperitoneal; IC, intracerebral.

tion, frozen sections were reacted with rat anti-mMCP-1 antibody (diluted 1/100), a specific marker for murine mast cells (24). Detection of labeled antigens was performed using avidin-biotin horseradish peroxidase kits (Vector, Burlingame, CA, U.S.A.) according to the manufacturer's instructions, with diaminobenzidine (Sigma Chemical Co) as the substrate. Negative controls were performed on adjacent slides by omission of the primary antibody. Control and experimental sections were processed at the same time. Examination of control sections failed to show detectable antibody labeling. To avoid regional and experimental variations in labeling intensity, sections from the various experimental groups that included comparable anatomic regions were treated simultaneously. Two investigators blinded to treatment group conducted the quantitative analysis, focusing on the neocortical plate and underlying white matter. Five randomly selected animals were included in each experimental group. In each animal, two nonadjacent sections were immunoreacted in successive experiments. Labeled cells from each section were counted in a $0.0625-\mathrm{mm}^{2}$ area of the cortical plate and periventricular white matter.

For Western blot analysis of mMCP-1, brains pretreated with IL-9 or PBS were homogenized in $20 \mathrm{mM}$ Tris- $\mathrm{HCl}(\mathrm{pH}$ 7.5) containing $10 \mathrm{mM}$ EDTA, $0.1 \mathrm{mg} / \mathrm{mL} 4$-(2-aminoethyl)benzenesulfonyl fluoride (Sigma Chemical Co), $2 \mu \mathrm{g} / \mathrm{mL}$ leupeptin (Sigma Chemical Co), $2 \mu \mathrm{g} / \mathrm{mL}$ aprotinin (Roche, Meylan, France), $0.35 \mu \mathrm{g} / \mathrm{mL}$ bestatin (Sigma Chemical Co), and
$0.35 \mu \mathrm{g} / \mathrm{mL}$ E64 (Sigma Chemical Co). Five brains were included in each experimental group. After centrifugations and protein content measurement, $40 \mu \mathrm{g}$ of protein from each sample was loaded on a NuPage $4-12 \%$ gel (Novex, San Diego, CA, U.S.A.) in NuPage MOPS-SDS buffer (Novex). Electrophoresis was performed, and samples were transferred to a PVDF membrane (Novex). Membranes were incubated for 30 min with MCP-1 rat antibody diluted $1 / 60$ in $100 \mathrm{mM}$ Tris buffer (pH 7.5) containing $0.9 \% \mathrm{NaCl}$ and $0.1 \%$ Tween 20 (Sigma Chemical Co). Detection of labeled antigens was with avidin-biotin horseradish peroxidase kits (Vector) according to the manufacturer's instructions, with Vector VIP (Vector) as the substrate. Western blot experiments were performed in triplicate.

Effects of IL-9 on brain inflammatory cells. After intraperitoneal injections of IL-9 $(n=5)$ or PBS $(n=5)$ between P1 and P5, as described above, Swiss pups were decapitated on P5. None of these pups received an excitotoxic challenge. The brains were fixed in formalin and embedded in paraffin. Coronal sections $6 \mu \mathrm{m}$ in thickness were cut through the frontoparietal neopallium and stained with toluidine blue and hematoxylin-eosin-saffron. Stained sections were examined for the presence of blood-derived or inflammatory cells by an investigator blinded to treatment group.

Effects of IL-9 on excitotoxic brain lesions and $\mathrm{mMCP}-1$ expression in mast cell-deficient mice. To further confirm the role of mast cells in IL-9-induced exacerbation of excitotoxic 
brain lesions, we used mast cell-deficient mice (25) obtained from mating of $\mathrm{WB} / \mathrm{ReJ} \mathrm{kit}^{\mathrm{W} /+}$ male mice and C57BL/6J $\mathrm{kit}^{\mathrm{W}-\mathrm{v} /+}$ female mice (Jackson Laboratory, Bar Harbor, ME, U.S.A.). W mutations are spontaneous mutations in the mouse kit gene (homolog of the human c-kit gene), which is important for three different stem cell populations: neural crest-derived melanocytes, hematopoietic stem cells, and primordial germ cells. The KIT transmembrane protein is a member of a growth factor receptor family with tyrosine kinase activity. KIT receptor and its ligand stem-cell factor are necessary for the attachment and proliferation of mast cells. Several dominant or semidominant mutations of kit gene have been described, and the corresponding phenotypes correlate with the level of KIT kinase persistent activity. Heterozygous WB/ReJ $\mathrm{kit}^{\mathrm{W} /+}$ and $\mathrm{C} 57 \mathrm{BL} / 6 \mathrm{~J} \mathrm{kit}{ }^{\mathrm{W}-\mathrm{v} /+}$ have variable amount of white spotting and are fertile, and $\mathrm{C} 57 \mathrm{BL} / 6 \mathrm{~J} \mathrm{kit}^{\mathrm{W}-\mathrm{v} /+}$ have a slight macrocytic anemia. When mated together, the first generation yields pups with easily recognizable separate phenotypes: 1 ) double heterozygous pups (WBB6F1/J kit ${ }^{\mathrm{W} / \mathrm{W}-\mathrm{v}}$ ) are completely white with black eyes and are mast cell-deficient. In the present study, these pups were called $\mathrm{kit}^{\mathrm{W} / \mathrm{W}-\mathrm{v}}$ mast cell-deficient mice. 2) Single heterozygous pups (WBB6F1/J $\mathrm{kit}^{\mathrm{W} /+}$ or WBB6F1/J kit ${ }^{\mathrm{W}-\mathrm{v} /+}$ ) have variable amount of white spotting and have normal mast cell populations. In the present study, these littermate pups were used as controls and called kit control littermates. 3) Wild-type WBB6F1/J kit ${ }^{+/+}$with no white spotting were not used in the present study.

$\mathrm{Kit}^{\mathrm{W} / \mathrm{W}-\mathrm{v}}$ mast cell-deficient pups and control littermates were pretreated with IL-9 or PBS as described above. After this pretreatment, pups were either used for ibotenate injection and lesion size determination (Table 1) or for mMCP-1 detection by immunohistochemistry and by Western blot analysis, as described above.

Effects of cromoglycate and antihistamine drugs on excitotoxic lesions. The effects of cromoglycate and antihistamine drugs on excitotoxic lesions were measured in Swiss pups pretreated with IL-9 before intracerebral injection of ibotenate, as described above.

Cromoglycate, an inhibitor of mast cell degranulation, was administered according to three different schedules (Table 1): 1) a single intraperitoneal injection of $40 \mathrm{mg} / \mathrm{kg}$ cromoglycate (Opticron, Rhone-Poulenc Rorer, Montrouge, France) diluted in $5 \mu \mathrm{L}$ of PBS and given $1 \mathrm{~h}$ before ibotenate administration on $\mathrm{P} 5$; 2) intraperitoneal injection of $400 \mathrm{mg} / \mathrm{kg}$ cromoglycate (Lomudal, Rhone-Poulenc Rorer) diluted in $20 \mu \mathrm{L}$ of $50 \%$ methanol and given twice a day (between $0800 \mathrm{~h}$ and $1000 \mathrm{~h}$ and between $1800 \mathrm{~h}$ and $2000 \mathrm{~h}$ ) from P1 to P5; and 3) a single intracerebral injection of $0.2 \mathrm{mg}$ cromoglycate (Lomudal) diluted in $2 \mu \mathrm{L}$ of $50 \%$ methanol and given $1 \mathrm{~h}$ before ibotenate injection on P5. Controls received injections of vehicle after similar schedules and injection routes.

Antihistamine drugs were diluted in a final volume of $4 \mu \mathrm{L}$ of PBS and injected intraperitoneally $1 \mathrm{~h}$ before ibotenate administration on P5. The following drugs or drug combinations were used (Table 1): the anti- $\mathrm{H}_{1}$ dexchlorpheniramine in a dose of $10 \mathrm{mg} / \mathrm{kg}$ (Polaramine, Schering-Plough, Levallois, France); the anti- $\mathrm{H}_{2}$ ranitidine in a dose of $50 \mathrm{mg} / \mathrm{kg}$ (Raniplex, Fournier, Dijon, France); 2 mg/kg dexchlorpheniramine +10 $\mathrm{mg} / \mathrm{kg}$ ranitidine; $10 \mathrm{mg} / \mathrm{kg}$ dexchlorpheniramine $+50 \mathrm{mg} / \mathrm{kg}$ ranitidine; and the anti- $\mathrm{H}_{3}$ thioperamide maleate at a dose of 40 or $500 \mathrm{mg} / \mathrm{kg}$ (Sigma Chemical Co).

To evaluate whether the neuroprotective effects of cromoglycate and antihistamine drugs were specific for IL-9exposed Swiss pups, two other control groups were included in some experiments (Table 1): pups pretreated with mouse recombinant IL-1 $\beta$ (Serotec, Oxford, U.K.) (dose and schedule of administration identical to those used for IL-9) or with PBS alone.

Statistical analyses. Quantitative data were expressed as the mean \pm SEM for each treatment group. Results were compared using $t$ tests or ANOVA with Dunnett's multiple comparison of means test.

\section{RESULTS}

Behavioral manifestations and mortality. Overall mortality was low after intracerebral ibotenate injections $(<5 \%)$. Pretreatment with IL-9 did not modify the mortality $(3.9 \%$ versus $4.3 \%$ ) or behavior (muscle tone, posture, activity-sleep alternation and duration, and suckling behavior) of the pups as compared with controls. The behavior and mortality rates $(4.1 \%$ versus $4.5 \%)$ were similar in $\mathrm{kit}^{\mathrm{W} / \mathrm{W}-\mathrm{v}}$ mast celldeficient pups and kit control littermates. Epileptic manifestations including clonic or tonic seizures and apneas were observed in almost all ibotenate-treated animals during the first $24 \mathrm{~h}$ after intracerebral injection. IL-9, IL-1 $\beta$, cromoglycate, and antihistamine treatments did not modify the frequency or pattern of these epileptic manifestations. Neither cromoglycate nor antihistamine drugs induced detectable sleepiness or hypotonia.

Effects of IL-9 and mast cell deprivation on excitotoxic brain lesions. Swiss pups, $\mathrm{kit}^{\mathrm{W} / \mathrm{W}-\mathrm{v}}$ mast cell-deficient pups, and kit control littermates pretreated with PBS and injected with ibotenate on P5 developed cortical lesions and white matter cysts (Fig. 1). The cortical lesions were typical, with dramatic neuronal loss in all neocortical layers and almost complete disappearance of neuronal cell bodies along the axis of ibotenate injection. The mean length of the lesion along the sagittal frontooccipital axis was $722 \pm 40 \mu \mathrm{m}$ in Swiss pups, $603 \pm 63 \mu \mathrm{m}$ in kit controls, and $731 \pm 86 \mu \mathrm{m}$ in $\mathrm{kit}^{\mathrm{W} / \mathrm{W}-\mathrm{v}}$ mast cell-deficient pups. The mean length of the periventricular white matter cysts along the sagittal frontooccipital axis was $372 \pm 31 \mu \mathrm{m}$ in Swiss pups, $347 \pm 27 \mu \mathrm{m}$ in kit controls, and $423 \pm 71 \mu \mathrm{m}$ in $\mathrm{kit}^{\mathrm{W} / \mathrm{W}-\mathrm{v}}$ mast cell-deficient pups.

In Swiss and kit control pups, pretreatment with IL-9 resulted in a statistically significant increase in the size of ibotenate-induced white matter and cortical plate lesions as compared with control pups pretreated with PBS (Fig. 1, $A-C$ ). In contrast, in $\mathrm{kit}^{\mathrm{W} / \mathrm{W}-\mathrm{v}}$ mast cell-deficient pups, IL-9 had no detectable effect on ibotenate-induced lesions of the white matter and cortical plate (Fig. 1D).

Effects of IL-9 on inflammatory cells and mast cells. Swiss pups pretreated with IL-9 showed no significant changes in cortical plate and white matter densities of blood-derived or inflammatory cells labeled by toluidine blue or hematoxylineosin-saffron as compared with pups pretreated with PBS (data 

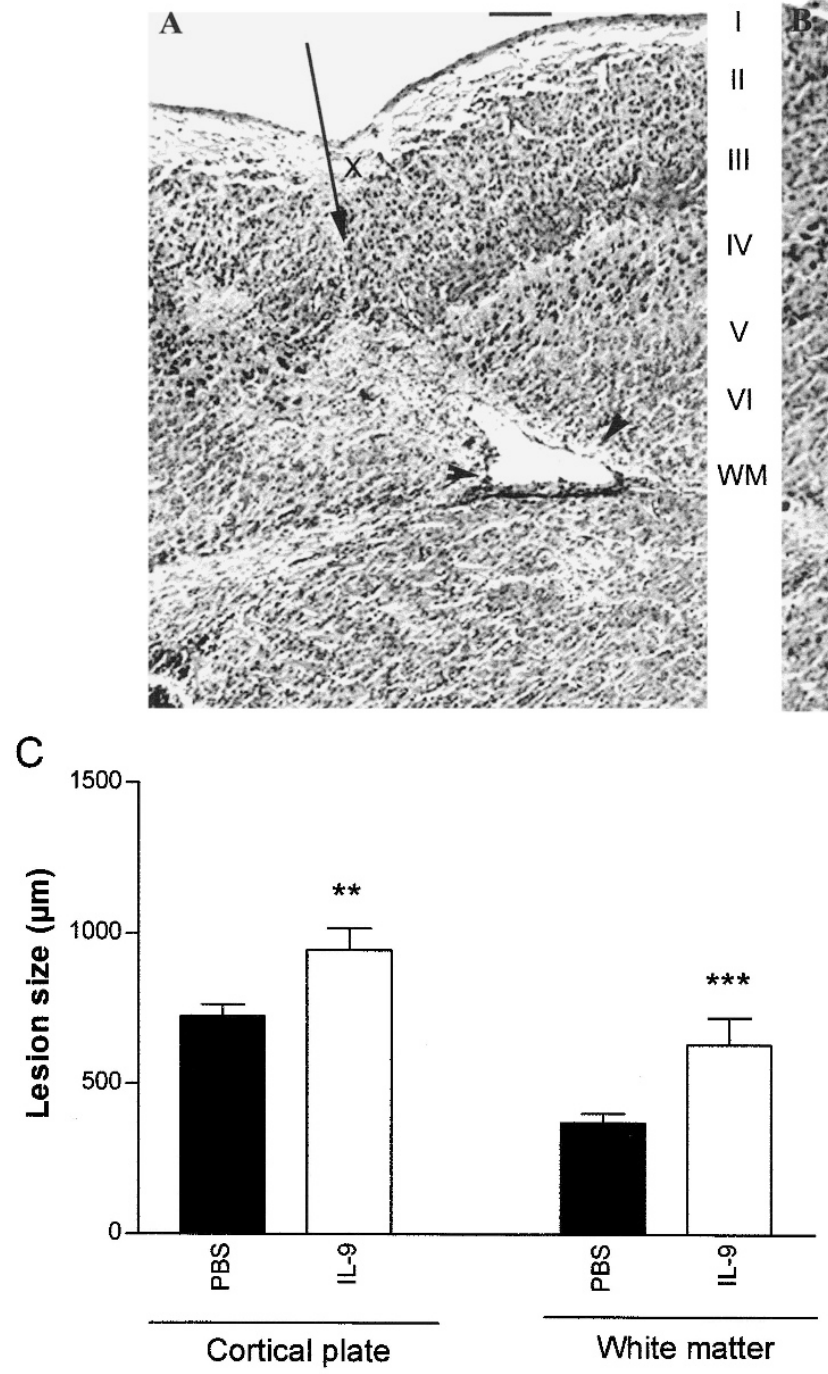

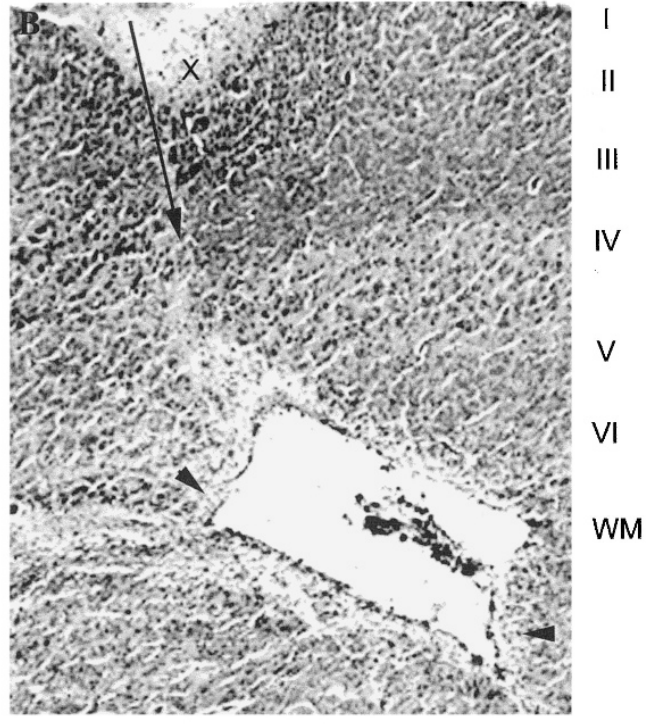

D

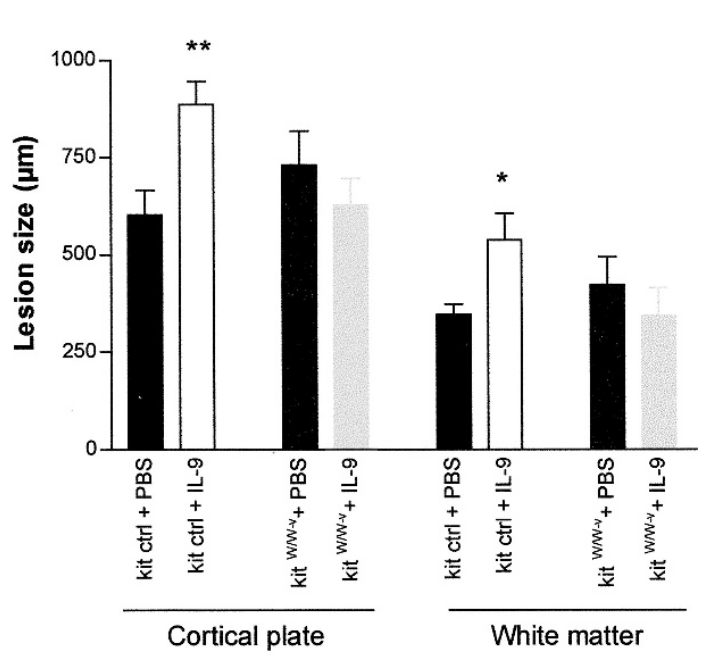

Figure 1. IL-9 pretreatment exacerbates excitotoxic brain lesions in Swiss and kit control pups, but not in kit ${ }^{\mathrm{W} / \mathrm{W}-\mathrm{v}}$ mast cell-deficient pups. Between P1 and P5, pups were pretreated with intraperitoneal PBS or $40 \mathrm{ng}$ of IL-9. Brain lesions were induced by intracerebral ibotenate injection on P5. The brains were studied on P10. $A, B$, cresyl violet-stained brain sections of Swiss pups pretreated with PBS $(A)$ or IL-9 $(B)$. The neuronal loss in layers II-VI (arrow points to epicenter of neuronal cell death and $X$ points to depression of layer II secondary to neuronal cell death) and the white matter (WM) cystic lesion (arrowheads) are typical. Bar $=40 \mu \mathrm{m} . C, D$, quantitative analysis of excitotoxic white matter and cortical plate lesions in Swiss pups $(C)$, and kit ${ }^{\mathrm{W} / \mathrm{W}-\mathrm{v}}$ mast cell- ${ }^{\mathrm{Weficient}}$ pups $\left(\mathrm{kit}^{\mathrm{W} / \mathrm{W}-\mathrm{v}}\right)$ and kit control littermates (kit ctrl) $(D)$. Each bar represents the mean \pm SEM length of the lesion along the sagittal frontooccipital axis. Numbers of analyzed brains included in each experimental group are given in Table 1. Asterisks indicate differences from controls (black bars; ${ }^{*} p<0.05, * * p<0.01, * * * p<0.001$ by ANOVA with Dunnett's multiple comparison test).

not shown). In particular, no mast cells labeled by toluidine blue were seen in the neopallium of control or IL-9-pretreated pups. In contrast, Swiss pups pretreated with IL-9 had a statistically significant increase in the density of mMCP-1positive cells in the white matter and cortical plate as compared with Swiss pups pretreated with PBS alone (Fig. 2, $A-C$ ). In both experimental groups, mMCP-1-positive cells were seen as clusters around blood vessels. Immunohistochemistry for mMCP-1 did not label any cells in the brains of $\mathrm{kit}^{\mathrm{W} / \mathrm{W}-\mathrm{v}}$ mast cell-deficient pups exposed to PBS or IL-9 (data not shown).

Western blot analysis using a specific antibody to mMCP-1 demonstrated a single band close to $31 \mathrm{kD}$ in PBS-treated Swiss mouse brains, but not in PBS-exposed $\mathrm{kit}^{\mathrm{W} / \mathrm{W}-\mathrm{v}}$ mast cell-deficient pups (Fig. 2D, lanes 1, 2, and 5). IL-9 treatment increased the brain mMCP-1 protein content of Swiss mice, but not of $\mathrm{kit}^{\mathrm{W} / \mathrm{W}-\mathrm{v}}$ mast cell-deficient pups (Fig. 2D, lanes 3, 4, and 6).

Effects of sodium cromoglycate and antihistamine drugs on excitotoxic lesions. In IL-9-pretreated Swiss pups, intraperitoneal (Fig. $3 A$ ) or intracerebral (Fig. $3 B$ ) injection of cromoglycate $1 \mathrm{~h}$ before ibotenate administration significantly reduced the severity of both the cortical plate and the white matter lesions. In contrast, similar cromoglycate treatment in Swiss pups pretreated with PBS (Fig. 3C) or IL-1 $\beta$ (Fig. 3D) did not result in significant neuroprotection against the excitotoxic insult.

Simultaneous blockade of $\mathrm{H}_{1}$ and $\mathrm{H}_{2}$ receptors by dexchlorpheniramine and ranitidine, respectively, protected both the 


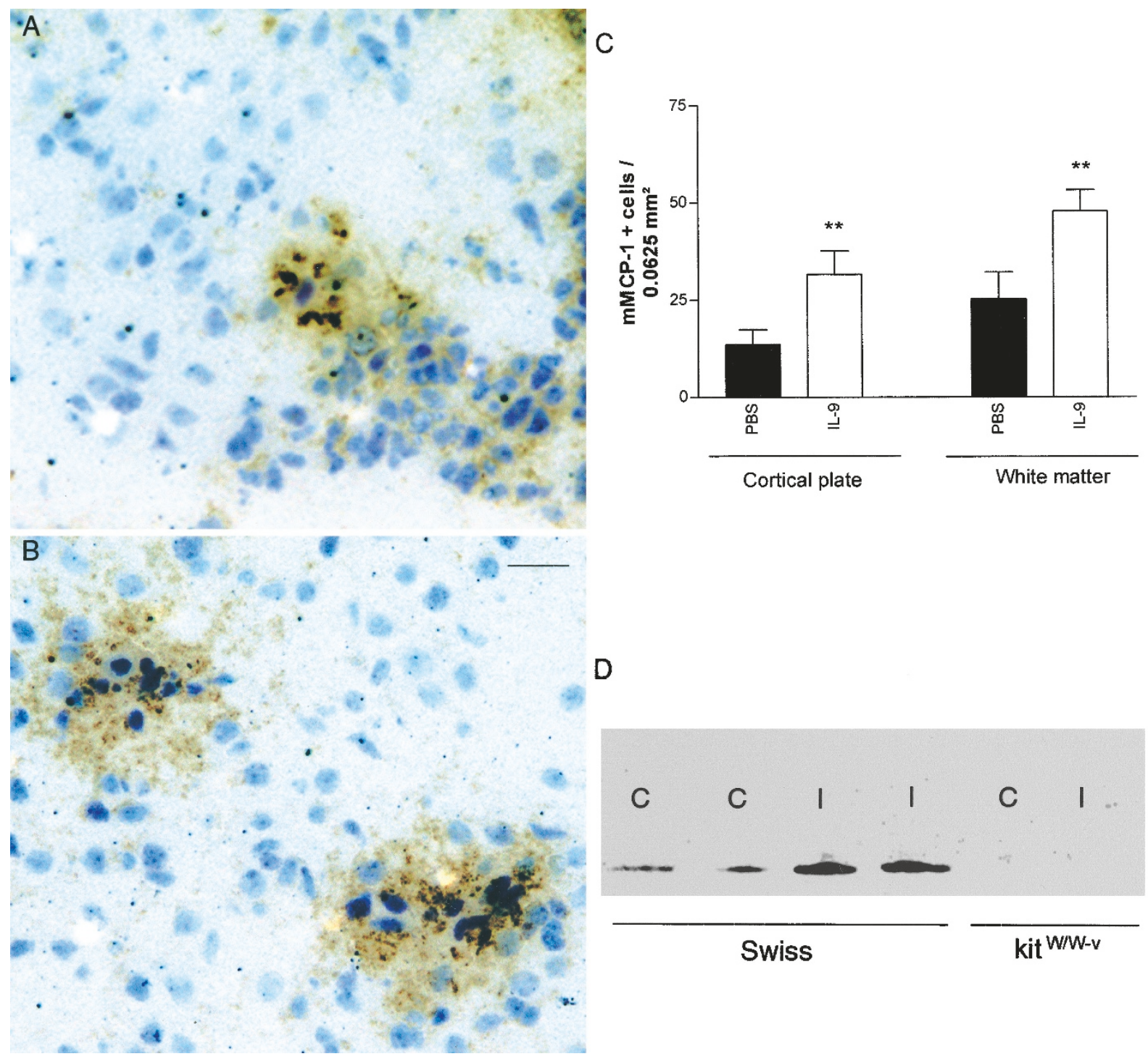

Figure 2. IL-9 pretreatment increases the density of mMCP-1-labeled brain cells. Between P1 and P5, Swiss pups were pretreated with intraperitoneal PBS or 40 ng IL-9, then killed on P5. $A, B$, immunohistochemistry for mMCP-1 performed in the frontoparietal neopallium of Swiss pups treated with PBS ( $A$ ) or IL-9 $(B)$. Bar $=20 \mu \mathrm{m}$. $C$, quantitative analysis of white matter and cortical plate cells labeled with anti-mMCP-1 antibody. In each experimental group, labeled cells were counted in 10 areas of $0.0625 \mathrm{~mm}^{2}$. To avoid regional variations, sections including comparable anatomic regions were analyzed in the various experimental groups. Asterisks indicate differences from controls (black bars; ${ }^{*} p<0.01$ by $t$ test). $D$, representative Western blot analysis of mMCP-1 immunoreactive proteins extracted from P5 brains. Western blot analysis was repeated in three successive experiments, with similar results. $C$, brains from pups pretreated with PBS; I, brains from pups pretreated with IL-9; $\mathrm{kit}^{\mathrm{W} / \mathrm{W}-\mathrm{v}}$, $\mathrm{kit}^{\mathrm{W} / \mathrm{W}-\mathrm{v}}$ mast cell-deficient pups.

cortical plate and the white matter against the excitotoxic challenge in Swiss pups pretreated with IL-9 (Fig. 4, $A$ and $B$ ). However, when administered separately, neither drug afforded significant protection in a similar experiment (Fig. 4, $A$ and $B$ ). As with cromoglycate, the anti- $\mathrm{H}_{1}-$ anti- $\mathrm{H}_{2}$ combination did not significantly affect the size of the excitotoxic lesions in pups pretreated with PBS (Fig. $4 C$ ). The anti- $\mathrm{H}_{3}$ drug thioperamide maleate afforded moderate protection of the neopallium against ibotenate, although only the cortical effect reached statistical significance (Fig. 4, $A$ and $B$ ).

\section{DISCUSSION}

The present study confirms that pretreatment of newborn mice with IL-9 exacerbates cortical plate and white matter excitotoxic lesions (11). Several lines of evidence are consis- tent with involvement of brain mast cells in this effect. 1) Mast cells are one of the key cellular targets of IL-9 (12). 2) IL-9 pretreatment increased the brain content of $\mathrm{mMCP}-1$, a marker for mast cells (24). Because the vast majority of brain $\mathrm{mMCP}$ 1-labeled cells were not stained with toluidine blue, we were unable to discriminate between increased expression of mMCP-1 in preexisting mast cells and increased density of brain mast cells. 3) Pretreatment of $\mathrm{kit}^{\mathrm{W} / \mathrm{W}-\mathrm{v}}$ mast celldeficient pups with IL-9 failed to exacerbate ibotenate-induced brain lesions. 4) Cromoglycate, an inhibitor of mast cell degranulation, reduced the excitotoxic brain lesions in IL-9pretreated pups.

B lymphocytes, some T-cell clones, and eosinophils are also among the described cell targets for IL-9 (12). Although histologic analysis showed no inflammatory cells in IL-9- 
A

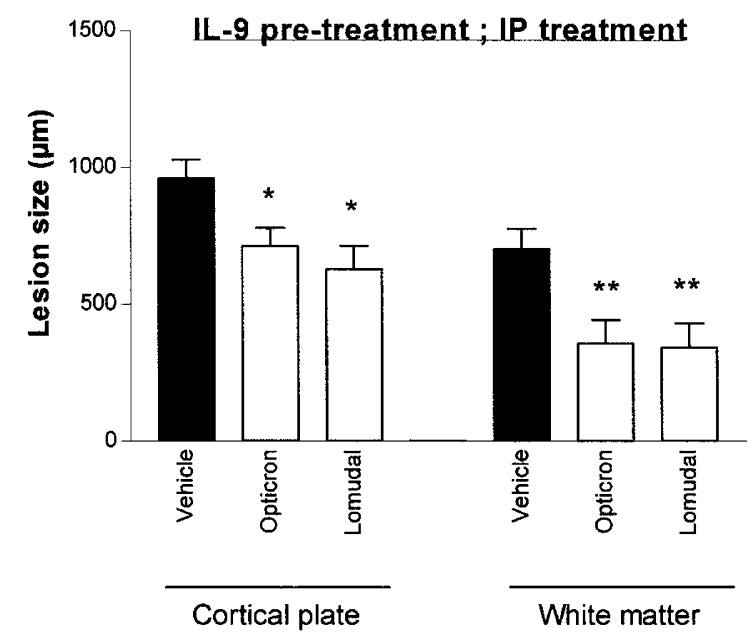

C

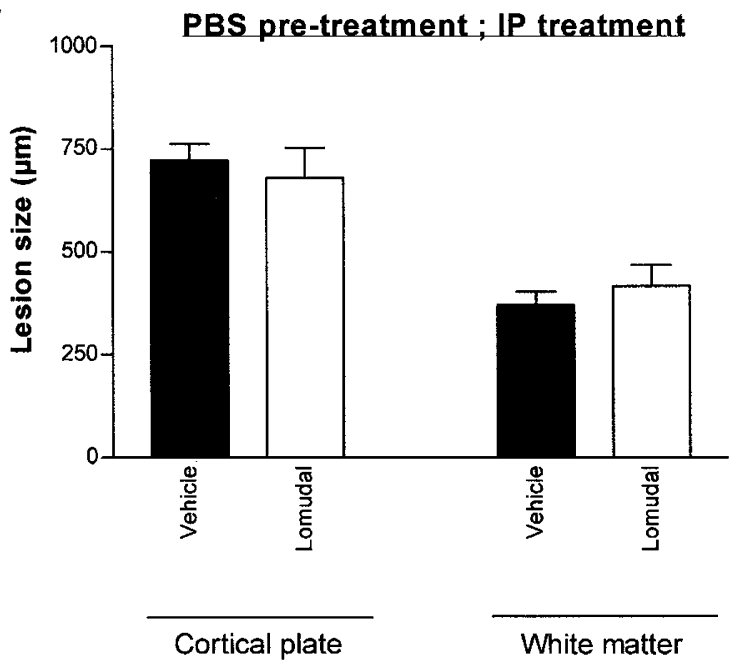

B
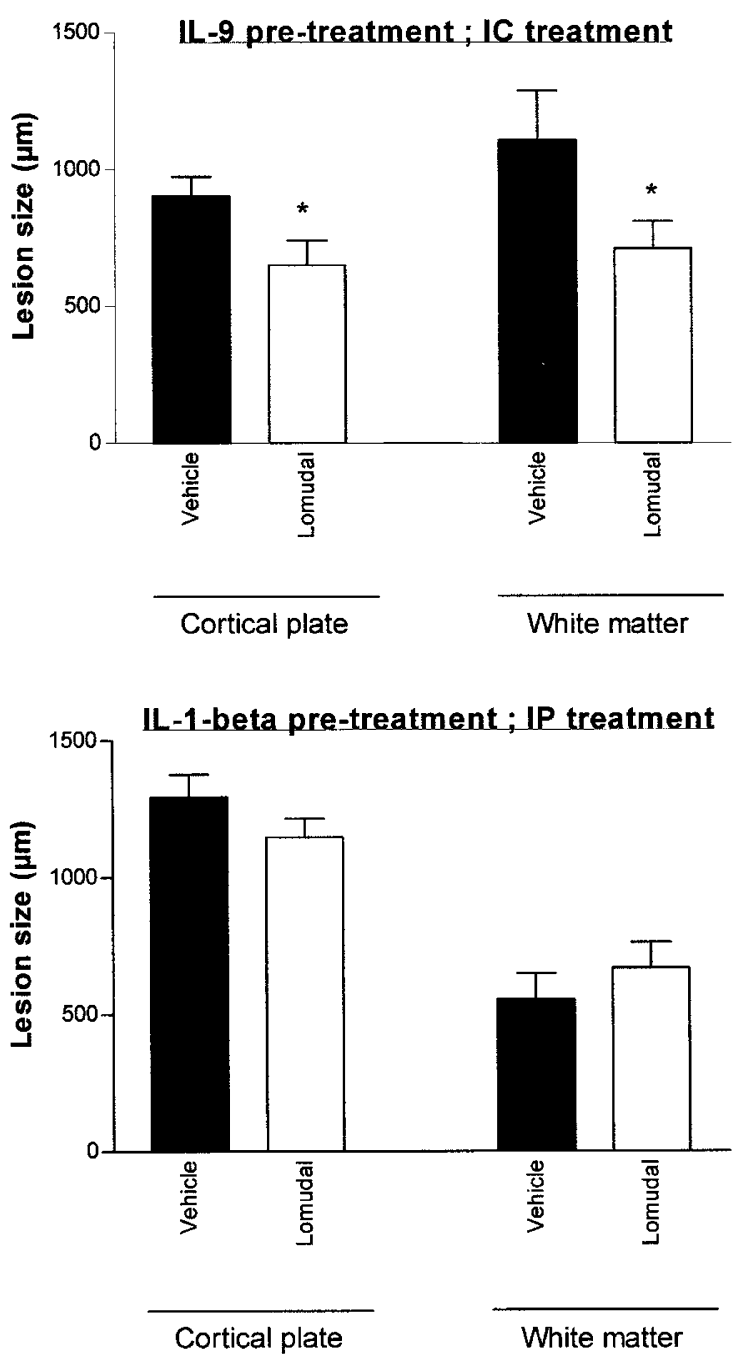

Figure 3. Cromoglycate affords neuroprotection to pups pretreated with IL-9. Quantitative analysis of excitotoxic white matter and cortical plate lesions. Between P1 and P5, Swiss pups were pretreated with $40 \mathrm{ng}$ of IL-9, $40 \mathrm{ng}$ of IL-1 $\beta$, or PBS injected intraperitoneally. Brain lesions were induced by an intracerebral ibotenate injection on P5. The brains were studied on P10. Each bar represents the mean \pm SEM length of the lesion along the sagittal frontooccipital axis. Numbers of analyzed brains included in each experimental group are given in Table 1 . Asterisks indicate differences from controls $\left[\right.$ black bars; ${ }^{*} p<0.05$, ${ }^{* *} p<0.01$ by ANOVA with Dunnett's multiple comparison test $(A)$ or $t$ test $(B)$ ]. $A$, effects of intraperitoneal $(I P)$ cromoglycate (Opticron, single injection of $40 \mathrm{mg} / \mathrm{kg}$ cromoglycate on P5; or Lomudal, daily injection of $400 \mathrm{mg} / \mathrm{kg}$ cromoglycate between P1 and P5) on ibotenate-induced lesions in pups pretreated with IL-9. B, effects of intracerebral (IC) administration of cromoglycate (Lomudal, single injection of $0.2 \mathrm{mg}$ of cromoglycate on P5) on ibotenate-induced lesions in pups pretreated with IL-9. C, effects of intraperitoneal (IP) administration of cromoglycate (Lomudal, daily injection of $400 \mathrm{mg} / \mathrm{kg} \mathrm{cromoglycate}$ between P1 and P5) on ibotenate-induced lesions in pups pretreated with PBS. D, effects of intraperitoneal (IP) administration of cromoglycate (Lomudal, daily injection of $400 \mathrm{mg} / \mathrm{kg}$ cromoglycate between P1 and P5) on ibotenate-induced lesions in pups pretreated with IL-1 $\beta$.

treated brains, further studies using specific markers for each of these cell types are needed to clarify the potential role of these cells in the present model. Alternatively to an effect on the immune system, IL-9 may act on other brain cells, such as neurons and astrocytes. IL-9 has been shown to stimulate cell differentiation of a neuronal cell line (26). We are currently investigating the effects of IL-9 on developing neurons.

As previously mentioned, activated mast cells can release several potentially toxic factors including histamine, serotonin, neutral proteases, cytokines, chemokines, and free radicals (18). Although proinflammatory cytokines (11) and free radicals $(9,23)$ have shown toxic effects in the present model, and the participation of other factors cannot be excluded, excess histamine release by IL-9-activated brain mast cells seems to play a key role in mediating excitotoxic lesion exacerbation by IL-9 pretreatment. Interestingly, antihistamine drugs were neuroprotective only when both $\mathrm{H}_{1}$ and $\mathrm{H}_{2}$ histamine receptors were blocked. $\mathrm{H}_{2}$ receptors are linked to both adenylate cyclase and phospholipase $\mathrm{C}$ in pathways that lead to calcium mobilization (27-29). The phospholipase C pathway is also used by $\mathrm{H}_{1}$ receptors. Existence of a common transduction pathway for $\mathrm{H}_{1}$ and $\mathrm{H}_{2}$ receptors would explain the lack of effect of anti- $\mathrm{H}_{1}$ or anti- $\mathrm{H}_{2}$ drugs given separately in our model. The mild neuroprotective effect of $\mathrm{H}_{3}$ receptor blockade in the present study suggests that $\mathrm{H}_{3}$ receptors may also contribute to the pathophysiology of excitotoxic neuronal death.

Although mMCP-1-positive cells were present in PBStreated brains, cromoglycate and antihistamine drugs had no 
A

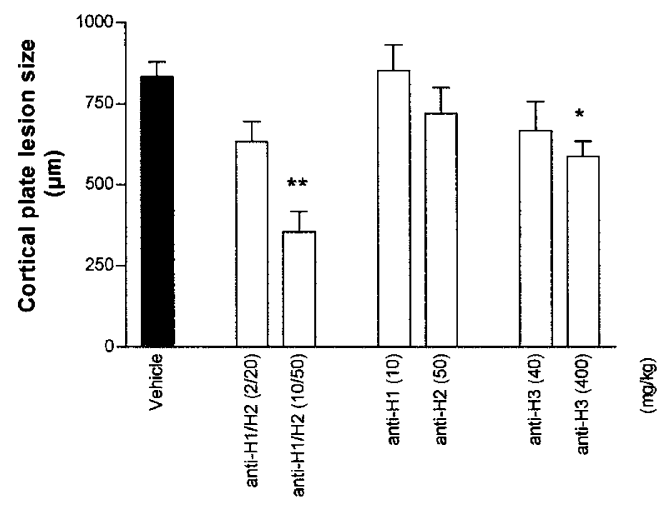

B

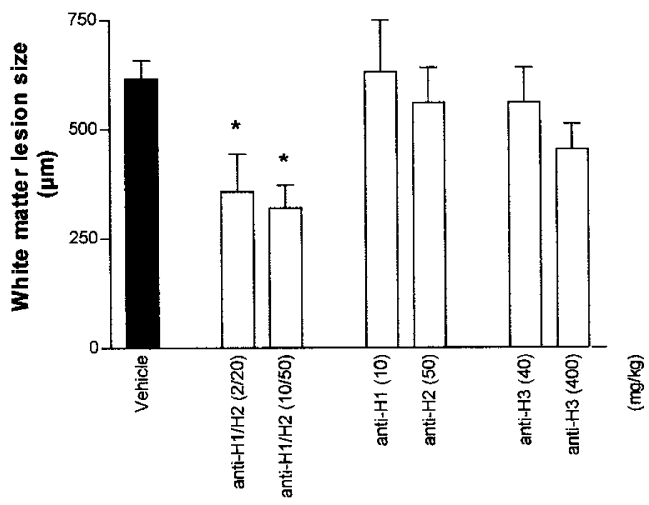

C

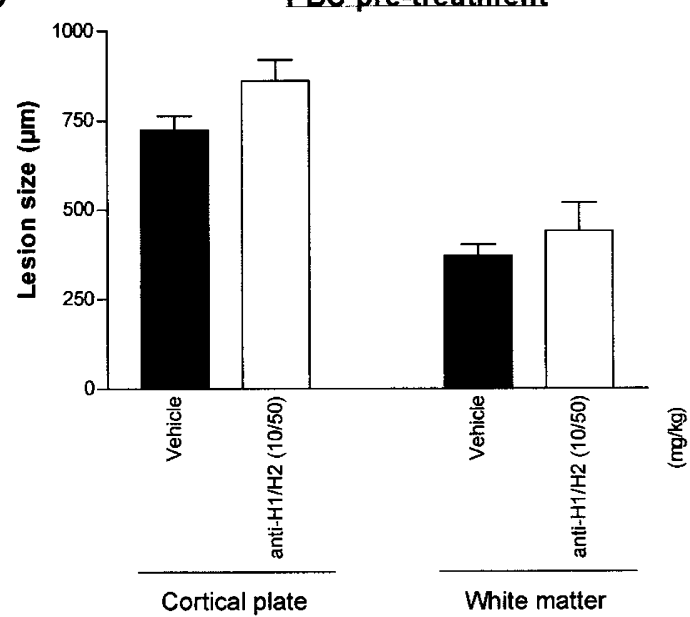

Figure 4. Antihistamine drugs are neuroprotective in pups pretreated with IL-9. Quantitative analysis of excitotoxic lesions. Between P1 and P5, Swiss pups were pretreated with intraperitoneal IL-9 in a dose of $40 \mathrm{ng}$ ( $A$, cortical plate lesions; $B$, white matter lesions) or with PBS $(C)$. Brain lesions were induced by an intracerebral ibotenate injection on P5. The brains were studied on P10. Each bar represents the mean \pm SEM length of the lesion along the sagittal frontooccipital axis. Numbers of analyzed brains included in each experimental group are given in Table 1. Asterisks indicate differences from controls (black bars; $* p<0.05, * * p<0.01$ by ANOVA with Dunnett's multiple comparison test). Anti- $\mathrm{H}_{1}$, dexchlorpheniramine (Polaramine); anti$\mathrm{H}_{2}$, ranitidine (Raniplex); anti- $\mathrm{H}_{3}$, thioperamide. protective effects against ibotenate in these mice, suggesting that, in the present model, brain mast cells contribute significantly to excitotoxic insults only if they have been exposed to IL-9. Similarly, cromoglycate had no protective effects against ibotenate-induced lesions in pups pretreated with the proinflammatory cytokine IL-1 $\beta$. NMDA receptors have been identified on mast cells, and activators of peripheral mast cell degranulation such as compound 40/80 seem to work by activating NMDA receptors (30). Taken together, these data could suggest that NMDA receptor-mediated degranulation of brain mast cells may require preexposure to IL-9.

In the present study, combined anti- $\mathrm{H}_{1}$ and anti- $\mathrm{H}_{2}$ drugs reduced cortical plate lesion size much more than the enhancement induced by IL-9 pretreatment, whereas cromoglycate only antagonized the IL-9-induced exacerbation of the excitotoxic lesion. Still, anti- $\mathrm{H}_{1}$ and anti- $\mathrm{H}_{2}$ treatment was inefficient in PBS-pretreated pups. As mentioned above activated mast cells can release neuronotoxic factors but also molecules with potential neuronotropic properties such as nerve growth factor and vasoactive intestinal peptide (18). The release of these latter protective factors combined with the blockade of the toxic effects of histamine could explain the remarkable cortical plate protection obtained with antihistamine drugs in IL-9-pretreated pups. In contrast, cromoglycate will inhibit mast cell degranulation and therefore prevent the release of both toxic and protective factors in IL-9-exposed pups.

Our experimental data [(11) and present study] are in keeping with the previously reported epidemiologic observation of increased mean levels of circulating cytokines at birth in patients who will later develop cerebral palsy when compared with control patients $(8)$. In aggregate, these data $[(8,11)$ and present study] suggest the existence of two different pathophysiologic mechanisms of cerebral palsy associated with different circulating cytokine profiles, namely, elevated proinflammatory cytokines with potential effects on brain microglia and elevated IL-9 levels with effects on brain mast cells. Treatments targeting mast cells may be effective in preventing cerebral palsy in patients with IL-9 elevation. Further clinical and neuropathologic studies of this working hypothesis are needed.

Intracerebral injection of cromoglycate mimicked the neuroprotective effects of an intraperitoneal injection, suggesting that IL-9 acted directly on mast cells in the brain. However, the present data do not exclude a contributory effect of IL-9stimulated peripheral mast cells and of other immune system changes induced by IL-9. Indeed, intraepithelial infiltration by mast cells has been reported in gut, trachea, and kidneys of IL-9 transgenic mice (31), and, as discussed above, B lymphocytes, some T-cell clones, and eosinophils are among the described cell targets for IL-9 (12). Studies of $\mathrm{kit}^{\mathrm{W} / \mathrm{W}-\mathrm{v}}$ mice, which lack mast cells in all the organs, do not permit the further discrimination among these central and peripheral effects of IL-9 on mast cell populations.

In conclusion, the present study identified brain mast cells as a key mediator of the IL-9-induced exacerbation of excitotoxic brain damage in the newborn mouse. Neuroprotective effects of drugs modulating mast cell activity were demon- 
strated in this model, potentially opening up new avenues for preventing brain lesions in some neonates at high risk for cerebral palsy.

\section{REFERENCES}

1. Pharoah P, Cooke T, Cooke RW, Rosenbloom L 1990 Birthweight specific trends in cerebral palsy. Arch Dis Child 65:602-606

2. Nelson KB, Ellenberg JH 1986 Antecedents of cerebral palsy: multivariate analysis of risk. N Engl J Med 315:81-86

3. Evrard P, Miladi N, Bonnier C, Gressens P 1992 Normal and abnormal development of the brain. In: Rapin I, Segalowitz SJ (eds) Handbook of Neuropsychology: Child Neuropsychology. Elsevier Science, Amsterdam, pp 11-44

4. Evrard P, Marret S, Gressens P 1995 Environmental determinants of brain development, with a special emphasis on the excitotoxic cascade at the consecutive developmental steps. In: Rating D (ed) Aktuelle Neuropädiatrie. Ciba-Geigy Verlag, Wehr, pp 22-33

5. Volpe JJ 1995 Neurology of the Newborn. WB Saunders, Philadelphia, pp 279-313

6. Murphy DJ, Sellers S, MacKenzie IZ, Yudkin PL, Johnson AM 1995 Case-contro study of antenatal and intrapartum risk factors for cerebral palsy in very preterm singleton babies. Lancet 346:1449-1454

7. Zupan V, Gonzalez P, Lacaze-Masmonteil T, Boithias C, d'Allest AM, Dehan M, Gabilan JC 1996 Periventricular leukomalacia: risk factors revisited. Dev Med Child Neurol 38:1061-1067

8. Nelson KB, Dambrosia JM, Grether JK, Phillips TM 1998 Neonatal cytokines and coagulation factors in children with cerebral palsy. Ann Neurol 44:665-675

9. Marret S, Mukendi R, Gadisseux JF, Gressens P, Evrard P 1995 Effect of ibotenate on brain development: an excitotoxic mouse model of microgyria and posthypoxiclike lesions. J Neuropathol Exp Neurol 54:358-370

10. Gressens P, Marret S, Hill JM, Brenneman DE, Gozes I, Fridkin M 1997 Vasoactive intestinal peptide prevents excitotoxic cell death in the murine developing brain. J Clin Invest 100:390-397

11. Dommergues MA, Patkai J, Renauld JC, Evrard P, Gressens P 2000 Pro-inflammatory cytokines and IL-9 exacerbate excitotoxic lesions of the newborn murine neopallium. Ann Neurol 47:54-63

12. Demoulin JB, Renauld JC 1998 Interleukin 9 and its receptor: an overview of structure and function. Int Rev Immunol 16:345-364

13. Dropp JJ 1976 Mast cells in mammalian brain. Acta Anat 94:1-21

14. Dropp JJ 1979 Mast cells in the human brain. Acta Anat 105:505-513

15. Lambracht-Hall M, Dimitriadou V, Theoharides TC 1990 Migration of mast cells in the developing brain. Dev Brain Res 56:151-159
16. Zhuang X, Silverman AJ, Silver R 1999 Distribution and local differentiation of mast cells in the parenchyma of the forebrain. J Comp Neurol 408:477-488

17. Gill CJ, Rissman EF 1998 Mast cells in the neonate musk shrew brain: implications for neuroendocrine immune reactions. Dev Brain Res 111:129-136

18. Silver R, Silverman AJ, Vitkovic L, Lederhendler I 1996 Mast cell in the brain: evidence and functional significance. Trends Neurosci 1:25-31

19. Dines KC, Powell HC 1997 Mast cell interactions with the nervous system: relationship to mechanisms of disease. J Neuropathol Exp Neurol 6:627-640

20. Zhuang X, Silverman AJ, Silver R 1999 Distribution and local differentiation of mast cells in the parenchyma of the forebrain. J Comp Neurol 408:477-488

21. Marret S, Bonnier C, Raymaekers JM, Delpech A, Evrard P, Gressens P 1999 Systemic administration of anti-NOS and anti-glycine protects against excitotoxic lesions in the developing mouse brain. Pediatr Res 45:337-341

22. Redecker C, Lutzenburg M, Gressens P, Evrard P, Witte OW, Hagemann G 1998 Patterns of excitability changes and glucose metabolism in experimentally induced cortical dysplasias. Cereb Cortex 8:623-634

23. Bac P, Maurois P, Dupont C, Pages N, Stables JP, Gressens P, Evrard P, Vamecq J 1998 Magnesium-deficiency-dependent audiogenic seizures (MDDASs) in adult mice: a nutritional model for discriminatory screening of anticonvulsant drugs and original assessment of neuroprotection properties. J Neurosci 18:4363-4373

24. Scudamore CL, McMillian L, Thornton EM, Wright SH, Newlands GF, Miller HR 1997 Mast cell heterogeneity in the gastrointestinal tract: variable expression of mouse mast cell protease-1 (mMCP-1) in intraepithelial mucosal mast cells in nematode-infected and normal BALB/c mice. Am J Pathol 150:1661-1672

25. Wershill BK, Galli SJ 1994 The analysis of mast cell function in vivo using mast-cell deficient mice. Adv Exp Med Biol 347:39-54

26. Mehler MK, Rozental R, Dougherty M, Spray DC, Kessler JA 1993 Cytokine regulation of neuronal differentiation of hippocampal progenitor cells. Nature 362:62-65

27. Delvalle J, Wang L, Gantz I, Yamada T 1992 Characterisation of $\mathrm{H}_{2}$ receptor: linkage to both adenylyl cyclase and $\left(\mathrm{Ca}^{2+}\right)$ signalling systems. Am J Physiol 263:G967G972

28. Mitsuhashi M, Payan DG 1992 Functional diversity of histamine and histamine receptors. J Invest Dermatol 98(suppl):8-11

29. Wang L, Gantz I, Delvalle J 1996 Histamine $\mathrm{H}_{2}$ receptor activates adenylate cyclase and PLC via separate GTP-dependent pathways. Am J Physiol 271:G613-G620

30. Purcell WM, Doyle KM, Westgate C, Atterwill CK 1996 Characterisation of a functional polyamine site on rat mast cells: association with a NMDA receptor macrocomplex. J Neuroimmunol 65:49-53

31. Godfraind C, Louahed J, Faulkner H, Vink A, Warnier G, Grencis R, Renauld JC 1998 Intraepithelial infiltration by mast cells with both connective tissue-type and mucosal-type characteristics in gut, trachea, and kidneys of IL-9 transgenic mice. J Immunol 160:3989-3996 